\title{
COVID-19 and Fontan: bioethical analysis derived from the need for hospital reconversion
}

\author{
Rebeca Gómezchico-Velascoํ, Claudia S. Villanueva-Sáenz², David Salazar-Lizárraga ${ }^{3,4}$, \\ Lucelli Yáñez-Gutiérrez ${ }^{4}$, and Horacio Márquez-González ${ }^{4,5 *}$
}

${ }^{1}$ Departamento de Nefrología, Hospital Infantil de México Federico Gómez; ${ }^{2}$ Asuntos Estudiantiles de la Facultad de Ciencias de la Salud, Centro Interdisciplinario de Bioética de la Universidad Panamericana, Facultad de Ciencias de la Salud; ${ }^{3}$ Servicio de Cardiología Pediátrica, Hospital Infantil de México Federico Gómez; ${ }^{4}$ Servicio de Cardiopatías Congénitas, Unidad Médica de Alta Especialidad Hospital de Cardiología, Centro Médico Nacional Siglo XXI; ${ }^{5}$ Departamento de Investigación Clínica, Hospital Infantil de México Federico Gómez. Mexico City, Mexico

\begin{abstract}
Background: Among congenital heart diseases, those with univentricular physiology are the most severe with the lowest survival. Fontan surgery (FS) is the procedure of choice, as it bypasses the flow from the caval veins to the pulmonary circulation but requires close monitoring for late complications. The SARS-CoV-2 (severe acute respiratory syndrome coronavirus 2) pandemic caused nations to prioritize the availability of human and material health resources to benefit those infected. This study aimed to evaluate the clinical consequences of hospital reconversion due to the COVID-19 pandemic in a univentricular heart clinic for patients with FS from the bioethical perspective. Methods: We conducted an analytical cross-sectional study in a captive cohort of patients with FS treated in a tertiary hospital with conversion to COVID-19 patient care. The consequences of discontinuation of follow-up were recorded. Qualitative variables were expressed as frequencies and percentages, and quantitative variables as medians and interquartile ranges (p25-p75). Comparison between the two groups was performed with the $\chi^{2}$ test. Results: We included 51 patients with a median age of 13 years and a follow-up of 5 years. The male: female ratio was 0.88:1.12, and $41 \%$ (21) presented failures. More than $90 \%$ of the patients presented needs for medications and imaging studies. The two patients cared for in palliative care discontinued their care. Conclusions: Continuity of care must be guaranteed for all patients who require it, so health policies are needed to ensure compliance with vulnerable groups.
\end{abstract}

Keywords: COVID-19. Congenital heart diseases. Fontan surgery. Pediatric. Mexico. Bioethics.

\section{COVID-19 y Fontan: análisis bioético derivado de la necesidad de reconversión hospitalaria}

\section{Resumen}

Introducción: Entre las cardiopatías congénitas, las de fisiología univentricular son el espectro más grave y con menor supervivencia. La cirugía de Fontan es el procedimiento de elección, ya que deriva el flujo de las venas cava a la circulación pulmonar, pero requiere un seguimiento estrecho de las complicaciones tardías. La pandemia por el SARS-CoV-2 (coronavirus 2 causante del síndrome respiratorio agudo grave) condicionó que las naciones priorizaran la disposición de

\section{Correspondence:}

*Horacio Márquez González

E-mail: horaciohimfg@gmail.com

Available online: 24-01-2022

Date of reception: 29-03-2021

Date of acceptance: $30-08-2021$

DOI: 10.24875/BMHIM.21000058
Bol Med Hosp Infant Mex. 2022;79(1):44-50

www.bmhim.com

1665-1146/C 2021 Hospital Infantil de México Federico Gómez. Published by Permanyer. This is an open access article under the CC BY-NC-ND license (http://creativecommons.org/licenses/by-nc-nd/4.0/). 
Ios recursos humanos y materiales en salud en beneficio de los infectados. El objetivo de este estudio fue evaluar las consecuencias clínicas de la reconversión hospitalaria por la pandemia de COVID-19 en una clínica de corazón univentricular de los pacientes con cirugía de Fontan desde el punto de vista bioético. Métodos: Se llevó a cabo un estudio transversal analítico en una cohorte cautiva de pacientes con cirugía de Fontan atendidos en un hospital de tercer nivel con reconversión para atención de pacientes por COVID-19. Se registraron las consecuencias derivadas de la interrupción del seguimiento. Las variables cualitativas se expresaron en frecuencias y porcentajes, y las cuantitativas en medianas y rangos intercuartílicos (p25-p75). La comparación entre ambos grupos se realizó con la prueba de $\chi^{2}$. Resultados: Se incluyeron 51 pacientes, con una mediana de edad de 13 años y seguimiento de 5 años. La relación de sexo masculino: femenino fue de 0.88:1.12, y el $41 \%$ (21) presentaron fallas. Más del $90 \%$ de los pacientes presentaron necesidades en el suministro de medicamentos y estudios de imagen. Los dos pacientes atendidos en cuidados paliativos suspendieron su atención. Conclusiones: La continuidad asistencial debe estar garantizada para todos los enfermos que la requieran, por lo que se necesitan políticas de salud para que esta continuidad se cumpla en los grupos vulnerables.

Palabras clave: COVID-19. Cardiopatías congénitas. Cirugía de Fontan. Pediatría. México. Bioética médica.

\section{Introduction}

Congenital heart disease (CHD) is the second leading cause of death in Mexico's children under five years of age. Among them, malformations with univentricular physiology require close follow-up that should be guaranteed indefinitely, given the number of complications and the fast rate at which they occur, since they reduce the quality of life and life expectancy ${ }^{1}$.

Fontan surgery (FS) is the palliative surgical treatment indicated for univentricular CHD. This surgery shunts the flow from the superior and inferior venae cavae to the pulmonary artery (through a fenestrated or non-fenestrated tube). Therefore, a hemodynamic system that causes the systemic venous return is created to exclude the subpulmonary ventricle and connect directly to the pulmonary system, ensuring that the cardiac mass remains exclusively systemic. This procedure may be the first step towards cardiac transplantation; however, transplantation is not always accessible in Latin American countries².

FS redistributes systemic venous return directly to the pulmonary circulation, causing pressure overload in the venous beds and in the splanchnic and lymphatic systems, which is a determining factor in developing diseases such as protein-losing enteropathy (PLE) and plastic bronchitis (PB). In addition, atrial overload and systemic ventricular morphology are arrhythmogenic phenomena and conditioners of heart failure. For these reasons, trained personnel in a hospital center should closely monitor such patients with the necessary infrastructure (complete imaging facilities, hemodynamic and electrophysiological study rooms, operating rooms, and intensive care areas) ${ }^{3}$.
In 2020, the pandemic caused by SARS-CoV-2 (severe acute respiratory syndrome coronavirus 2) reached its first case in Mexico during the last week of February and spread logarithmically, affecting the working population and with higher lethality starting in the fifth decade of life. ${ }^{4}$ As a result, the national health system was forced to implement hospital conversion strategies prioritizing the greater availability of human and biomedical resources for the benefit of infected persons requiring hospitalization. Therefore, tertiary-level hospitals were the first to be used.

The reconversion of hospitals led to a group of people with specific diseases being displaced to a second plane, causing consultations, drug dispensing, tests, and procedures to be deferred. Hospitals caring for patients with ischemic heart disease with FS found themselves in this situation because they represented a small group ${ }^{5}$.

The objectives of this study were to evaluate the clinical consequences in patients with FS (complications of the disease, functional class) and the quality of care (follow-up, the performance of procedures, dispensing of medications) produced by hospital conversion due to the COVID-19 pandemic and to compare whether these variables were more frequent in the group of patients with FS failure, and to carry out an ethical discussion of these actions as well.

\section{Methods}

We conducted a comparative cross-sectional study in a captive cohort of patients with CHD of univentricular physiology repaired with FS in a tertiary care hospital in Mexico City. Patients in the initial cohort (those who initially signed the informed consent form) who 
accepted the telephone invitation to participate and filled out an online questionnaire were included; those with incomplete, duplicate, or inconsistent identification data were excluded. At the onset of Phase II of the SARS-CoV-2 pandemic response (March 24, 2020), mobility in Mexico City was restricted, and scheduled consultations were deferred or cancelled ${ }^{6}$. For this reason, on January 1, 2021, a medical appointment status update was initiated at the hospital where the study was conducted, and parents or guardians interested in the study were invited by telephone to provide their e-mail addresses to receive the link to the questionnaire on their children's status. The questionnaire asked about the following aspects:

- Attitudes adopted during quarantine: home confinement, place of residence during this period, physical activity, standard protective measures (distancing, masks, gloves, face shield), and updated vaccination status.

- Conditions for infection, including living with adults at high risk of exposure to infection or confirmed cases.

- Personal history of symptoms or exposure to the disease.

- Treatment: accessibility of medications, complications associated with drugs such as anticoagulants or antiplatelet agents.

- About the underlying disease: functional class, heart failure requiring hospitalization, consequences of deferral of scheduled procedures, and accessibility to reschedule new appointments.

Two comparison groups were selected based on FS functionality, considering as failure patients with cyanosis (oxygen saturation $\leq 90 \%$ ), PLE, PB, or heart failure (systemic ventricular ejection fraction $<50 \%$ ). In addition, the follow-up of patients in palliative care was particularized.

\section{Statistical analysis}

Qualitative variableswere expressed as frequenciesand percentages; quantitative variableswere expressedasmediansandinterquartile ranges (p25-p75). Comparisonbetween the two groups was performed with the $\chi^{2}$ test. The statistical software used was SPSS version 20 for MAC.

\section{Results}

Fifty-one patients met the selection criteria. The median age was 13 (6-18) years, and the median follow-up was 5(1.2-12) years. The male: female ratio was 0.88:1.12.

Table 1. General characteristics of the patients

\section{Variable}$$
\text { (1) }
$$

Sex
Male
Female

Age (years)*

Congenital heart disease

\begin{tabular}{l|l|l|} 
Tricuspid atresia & 26 & 51 \\
\hline
\end{tabular}

Pulmonary atresia without VSD

\begin{tabular}{l|l|l|}
\hline Double entry into SV & 12 & 24 \\
\hline
\end{tabular}

\begin{tabular}{|l|l|l|} 
Time of the procedure (years) & 5 & $1.2-12$ \\
\hline
\end{tabular}

Medications

\begin{tabular}{l|l|l|}
\hline Anticoagulants & 23 & 45 \\
\hline Antiplatels
\end{tabular}

$\begin{array}{lll}\text { Antiplatelets } & 40 & 78\end{array}$

\begin{tabular}{l|l|l} 
ACEI & 19 & 37
\end{tabular}

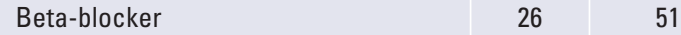

\begin{tabular}{ll|l} 
Digitalis & 2 & 4
\end{tabular}

Functional class* II (I-IV)

Vaccines

\begin{tabular}{l|l|l} 
Influenza & 48 & 94 \\
\hline
\end{tabular}

\begin{tabular}{l|l|l|} 
Pneumococcal & 43 & 84
\end{tabular}

\begin{tabular}{l|l|l|}
\hline Fontan system dysfunction & 21 & 41
\end{tabular}

\begin{tabular}{l|l|l|} 
Suspicion of SARS-CoV-2 & 6 & 12
\end{tabular}

\begin{tabular}{l|l|l|} 
Hospitalization & 3 & 6
\end{tabular}

*Median (25 and 75 percentiles).

ACEI, angiotensin-converting enzyme inhibitors; SARS-CoV-2, severe acute respiratory syndrome coronavirus 2 ; $S V$, single ventricle; VSD, ventricular septal defect.

Tricuspid atresia was the most frequent malformation in $26(51 \%)$ cases. Ofthetotal, $21(41 \%)$ patients presented some type of dysfunction, and the median functional class was II (I-IV). The remaining characteristics are shown in Table 1.

Subjects with and without FS dysfunction showed statistically significant differences (with a higher proportion of needs) in the first group in the following variables: uncontrolled anticoagulation (62\% vs. $33 \%$ ), additional expenditure for drug purchase, and hospitalization (95\% vs. $30 \%)$, delay in laboratory tests $(71 \%$ vs. $40 \%)$, CT scans $(29 \%$ vs. $7 \%)$, Holter ( $24 \%$ vs. $13 \%)$, magnetic resonance imaging (MRI) (10\% vs. $3 \%)$ and need for cardiac catheterization (33\% vs. $7 \%$ ). The remaining characteristics are shown in Table 2.

In terms of mobility, all patients reported having stayed in confinement, following the health authorities' recommendations: $14 \%$ reported having been in contact with a person with suspected SARS CoV-2 infection and $8 \%$ with a confirmed case. However, none of the FS 
Table 2. Comparison of sociodemographic, clinical, and therapeutic characteristics between patients with and without Fontan system dysfunction

\begin{tabular}{|c|c|c|c|c|c|c|c|}
\hline & \multicolumn{2}{|c|}{ Total } & \multicolumn{2}{|c|}{ Dysfunction } & \multicolumn{2}{|c|}{ No dysfunction } & \multirow[t]{2}{*}{$p$-values } \\
\hline & n & 51 & n & 21 & n & 30 & \\
\hline $\begin{array}{l}\text { State* } \\
\text { Mexico City } \\
\text { Queretaro } \\
\text { Guerrero } \\
\text { Chiapas } \\
\text { Oaxaca } \\
\text { Puebla }\end{array}$ & $\begin{array}{c}14 \\
15 \\
9 \\
7 \\
3 \\
3\end{array}$ & $\begin{array}{l}27 \\
29 \\
18 \\
14 \\
6 \\
6\end{array}$ & $\begin{array}{l}6 \\
6 \\
4 \\
2 \\
2 \\
1\end{array}$ & $\begin{array}{c}29 \\
29 \\
19 \\
10 \\
10 \\
5\end{array}$ & $\begin{array}{l}8 \\
9 \\
5 \\
5 \\
1 \\
2\end{array}$ & $\begin{array}{l}27 \\
30 \\
17 \\
17 \\
3 \\
7\end{array}$ & $\begin{array}{l}\text { NS } \\
\text { NS } \\
\text { NS } \\
\text { NS } \\
\text { NS } \\
\text { NS }\end{array}$ \\
\hline Time of Fontan follow-up* & 9 & 18 & 6 & $4-8$ & 3 & $1-6$ & 0.05 \\
\hline Suspected SARS-CoV-2 & 7 & 14 & 3 & 14 & 4 & 13 & NS \\
\hline Contacts with SARS-CoV-2 & 4 & 8 & 2 & 10 & 2 & 7 & NS \\
\hline $\begin{array}{l}\text { Modifications } \\
\text { Insomnia } \\
\text { Weight gain } \\
\text { Increased cyanosis } \\
\text { Psychological counseling }\end{array}$ & $\begin{array}{c}13 \\
10 \\
8 \\
1\end{array}$ & $\begin{array}{c}25 \\
20 \\
16 \\
2\end{array}$ & $\begin{array}{l}6 \\
3 \\
7 \\
1\end{array}$ & $\begin{array}{c}29 \\
14 \\
33 \\
5\end{array}$ & $\begin{array}{l}7 \\
7 \\
1 \\
0\end{array}$ & $\begin{array}{c}23 \\
23 \\
3 \\
0\end{array}$ & $\begin{array}{l}\text { NS } \\
\text { NS } \\
\text { NS } \\
\text { NS }\end{array}$ \\
\hline $\begin{array}{l}\text { Modifications } \\
\text { Anticoagulation failure } \\
\text { Pacemaker failure } \\
\text { Suspension of drug administration } \\
\text { Extra care expenses } \\
\text { Metabolic dyscontrol } \\
\text { Loss of follow-up } \\
\text { Hospitalization }\end{array}$ & $\begin{array}{c}23 \\
2 \\
20 \\
29 \\
8 \\
46 \\
9\end{array}$ & $\begin{array}{c}45 \\
4 \\
39 \\
57 \\
16 \\
90 \\
18\end{array}$ & $\begin{array}{c}13 \\
1 \\
9 \\
20 \\
5 \\
19 \\
7\end{array}$ & $\begin{array}{c}62 \\
5 \\
43 \\
95 \\
24 \\
90 \\
33\end{array}$ & $\begin{array}{c}10 \\
1 \\
11 \\
9 \\
3 \\
27 \\
2\end{array}$ & $\begin{array}{c}33 \\
3 \\
37 \\
30 \\
10 \\
90 \\
7\end{array}$ & $\begin{array}{c}0.001 \\
N S \\
N S \\
<0.0001 \\
0.001 \\
N S \\
N S\end{array}$ \\
\hline $\begin{array}{l}\text { Loss of studies or follow-up } \\
\text { Laboratory } \\
\text { CT scan } \\
\text { Holter } \\
\text { Magnetic resonance imaging } \\
\text { Cardiac catheterization }\end{array}$ & $\begin{array}{c}27 \\
8 \\
9 \\
3 \\
9\end{array}$ & $\begin{array}{c}53 \\
16 \\
18 \\
6 \\
18\end{array}$ & $\begin{array}{l}15 \\
6 \\
5 \\
2 \\
7\end{array}$ & $\begin{array}{l}71 \\
29 \\
24 \\
10 \\
33\end{array}$ & $\begin{array}{c}12 \\
2 \\
4 \\
1 \\
2\end{array}$ & $\begin{array}{c}40 \\
7 \\
13 \\
3 \\
7\end{array}$ & $\begin{array}{c}0.001 \\
<0.0001 \\
0.001 \\
0.001 \\
0.0001\end{array}$ \\
\hline $\begin{array}{l}\text { Clinical consequences } \\
\text { Impairment of functional class* }\end{array}$ & 4 & 8 & 3 & 14 & 1 & 3 & 0.001 \\
\hline
\end{tabular}

patients became infected. Furthermore, 25\% reported sleep disturbance, and $20 \%$ reported an increase in body weight.

The two patients in the palliative care program discontinued care from the moment of hospital reconversion and did not receive medication for symptom control (analgesics, sedatives, antidepressants, and oxygen). No patients have died to date.

\section{Discussion}

This article discusses some of the bioethical dilemmas of health care delivery in pediatric patients with rare diseases in the context of the COVID-19 pandemic. Health authorities and health professionals have made decisions that prioritize the distribution of human and technological resources based on ethical and moral arguments-for example, identifying the conditions of the vulnerability of patients infected by SARS-Cov-2 and placing them at the forefront of care. Unfortunately, this decision implies that hospitals treating rare diseases but with a high demand for specialized services have had to stop caring for these patients to reduce population demand due to the severe conditions caused by SARS-CoV-2.

Patients with CHD, specifically those with a cardiac malformation with univentricular physiology, require medical consultations with a narrow window of time to identify and treat early complications secondary to cyanosis, thrombosis, heart failure, pacemaker generator 
depletion to maintain quality of life. In addition, there is a deficit in the care of patients with univentricular physiology because national life expectancy and the possibility of cardiac transplantation are lower than in other countries ${ }^{6,7}$.

In a pandemic, such as the current one, four necessary epidemiological actions can be distinguished: containment, deferral, research, and mitigation, which will be discussed below:

- In the containment phase, there are problems of restriction of fundamental human rights, such as freedom of movement and the performance of daily activities (such as working or going to school). The limitation of the population's mobility with forced home isolation is intended to prevent the spread of the virus. The principle of equity prevails since protecting at-risk groups requires the inhabitants to show solidarity, even sacrificing their autonomy to obtain a primary common good. This principle applies specifically to patients with FS, considering that there are nine public hospitals with experience in performing total cavopulmonary bypass in Mexico. Seven are located in Mexico City (national epidemic center of the pandemic), which were all converted to care for patients with COVID- $19^{9}$.

- In the deferral stage, each country decides the degree of restriction it imposes on its inhabitants and evaluates it based on scientific evidence of the behavior of the disease. With these arguments, the impact on public health and the insurmountable limits of each right are weighed-for example, isolating patients from their families in hospitalization areas $^{10}$.

- Research phase. This crisis demonstrated the urgency of having treatments and vaccines available, despite the significant mismatch between the time of the methodological phases of the research work and the needs of the populations affected by the virus. Specifically, in vaccine research, vaccine efficacy and safety analysis was reduced to the shortest possible time to initiate an application to the population. This situation limits research in pediatric groups and forces decisions to be made, such as not including children in the vaccination program.

- The mitigation phase consists of allocating resources, which will always be scarce or insufficient, depending on the needs. In the context of the COVID-19 pandemic, beds with oxygen intakes and intensive care units with mechanical ventilators, indispensable for treating patients undergoing surgery, such as patients with FS, were required on a massive scale. Due to this situation, such procedures were deferred ${ }^{9}$. As a result, the dynamics of our patients' medical care changed in these months of the pandemic, some of them in an unrecoverable therapeutic window of opportunity that could leave irreversible sequelae ${ }^{9}$.

Health strategies must address not only the medical dimensions of the epidemic, although they are a priority, but also human rights and the specific consequences of each pathology. Healthcare must remain available to all people without discrimination or exclusion. When making decisions on the distribution of services, different approaches must be considered. The utilitarian approach (understood as maximizing the benefit for the most significant number of people for the longest possible time) prioritizes care for adults (as the group with the highest number of infections) over pediatric populations. There is also the dilemma bias, the search for quick solutions without ethical commitment to solving health problems ${ }^{8}$. Both point to a high-risk situation in which the rights of individuals can easily be violated, as individual benefits are subordinated to collective ones. The classic concept includes the maximization of collective benefits ${ }^{11}$.

In a community, individual human rights cannot be subordinated to the maximization of collective benefits. PAHO (Pan American Health Organization) has stated that, in the Americas, the level of neglect of other diseases, such as diabetes, hypertension, heart disease, among others, has been devastating. Therefore, implementing a process of regularization or return to normality to correct the delay in providing follow-up consultations, pending diagnoses, treatments, and rehabilitation displaced by the hospital conversion ${ }^{7}$ has been planned by the different health institutions in Mexico. In personalism, every human being is a "person with the dignity of his or her own," who cannot be impoverished by social and medical conditions so that another person or society can neglect no life. Personalism reminds the healthcare professional that all human beings have the same value and dignity ${ }^{12}$.

Pediatric diseases, in this case, CHD of univentricular physiology, are always a family problem, so that the parents of patients with this pathology have experienced the hospital conversion and the deferral of follow-up of their children's pathology with particular anxiety. In addition, theeconomic impacthas been significant even for the purchase of the necessary medications. 
Table 3. Bioethical argumentation on the consequences of hospital conversion

\begin{tabular}{|c|c|c|}
\hline Principle & Ensure & Pandemic context \\
\hline Autonomy & $\begin{array}{l}\text { Guarantee the "best interests of the child," in which } \\
\text { health-related decisions are executed under the } \\
\text { direction of parents or guardians and health personnel. } \\
\text { The State must provide children with the guarantee of } \\
\text { their physical and emotional development, executed by } \\
\text { parents under the Child's Rights. It should be privileged } \\
\text { as long as it does not harm other people }\end{array}$ & $\begin{array}{l}\text { Parents' activities were impaired because they could } \\
\text { not comply with established schedules for } \\
\text { consultations, laboratory or cabinet studies, and } \\
\text { dispensing of medications due to lack of freedom to } \\
\text { make decisions, confinement, and limited access to } \\
\text { medical care }\end{array}$ \\
\hline Beneficence & $\begin{array}{l}\text { Guarantee the moral obligation to act for the benefit of } \\
\text { others, cure harm, and promote good or welfare } \\
\text { without discrimination to not generate inequalities. } \\
\text { Beneficence must be balanced against potential harm. } \\
\text { The absence of medical care should be avoided }\end{array}$ & $\begin{array}{l}\text { There is a lack of healthcare services to care for } \\
\text { vulnerable groups. The pandemic has highlighted } \\
\text { patient selection for treatment, vaccines, and } \\
\text { intensive care, among others }\end{array}$ \\
\hline Non-maleficence & $\begin{array}{l}\text { Ensure the oldest principle of medical practice: first, } \\
\text { not harm ("primum non nocere"), prevent harm and } \\
\text { preserve life }\end{array}$ & $\begin{array}{l}\text { An adequate public policy was not created to } \\
\text { guarantee the articulated administration of goods and } \\
\text { services. It was impossible to offer the "minimum" } \\
\text { that corresponds to these patients. This principle was } \\
\text { not complied with due to the magnitude of the health } \\
\text { crisis }\end{array}$ \\
\hline Justice & $\begin{array}{l}\text { Ensure equity in the distribution of costs and benefits, } \\
\text { the distribution of resources according to needs must } \\
\text { be possible for all. Give to each one what is due to } \\
\text { him/her. } \\
\text { Distributive justice, according to Aristotle, means what } \\
\text { is just or right concerning the allocation of goods in a } \\
\text { society. The first principle of distributive justice is } \\
\text { known as egalitarianism, which consists of giving an } \\
\text { equal amount of goods to members of society. } \\
\text { Equity seeks to implement justice and equality of } \\
\text { opportunity, respecting the particular characteristics of } \\
\text { the individual to give each one what is due to him/her }\end{array}$ & $\begin{array}{l}\text { The pandemic forced decision-making by applying } \\
\text { public policies to favor the care of those infected by } \\
\text { COVID-19 (positive discrimination or affirmative } \\
\text { action), even using resources that correspond to other } \\
\text { patients (such as those that underwent Fontan } \\
\text { surgery) }\end{array}$ \\
\hline
\end{tabular}

The parents of these children are aware that constant monitoring and medical care are required and have experienced this situation as a radical change in the care, plans, priorities, and even in the expression of their children's emotions. Although there are no cohort studies of patients with CHD evaluating the consequences of COVID-19 or limited access to health services, cyanosis (due to the risk of thrombosis), arrhythmias, and ventricular dysfunction have been identified as poor prognostic variables that justify continuity of healthcare services ${ }^{13}$.

The United Nations Secretary-General has expressed the lack of care for children with chronic diseases, citing: "I am particularly concerned about the welfare of the world's children in this pandemic," and has made an urgent appeal to the leaders of all countries to protect the rights of children and safeguard their well-being ${ }^{12}$.

With the reconversion of high specialty hospitals, where only patients with COVID-19 have been treated, and the suspension of follow-up consultations for chronic patients, especially children with severe pathologies such as CHD with FS, the four main principles of bioethics have been affected (Table 3$)^{14}$.

Finally, the following conclusions are mentioned:

- Bioethics training for healthcare professionals and leaders who make decisions at the global, national, and institutional levels should be prioritized since these bioethical dilemmas arise daily and are latent in times of crisis such as this pandemic.

- Continuity of care must be guaranteed, even in times of health crises. Chronic patients cannot be displaced because the principles of autonomy, beneficence, and non-maleficence must be preserved. Similarly, equity in treatment highlights the strength of healthcare systems since displaced patients are practically left to die, and decision-makers must ask themselves whether it is reasonable to underestimate these groups.

- For now, the priority is to address the devastation caused by the pandemic. Once the crisis is over, 
public services must return to guaranteeing equal care for all groups, including the most vulnerable, such as children with CHD with and without surgery, for an elementary reason of justice.

\section{Ethical disclosures}

Protection of human and animal subjects. The authors declare that no experiments were performed on humans or animals for this study.

Confidentiality of data. The authors declare that they have followed the protocols of their work center on the publication of patient data.

Right to privacy and informed consent. The authors have obtained the written informed consent of the patients or subjects mentioned in the article. The corresponding author has this document.

\section{Conflicts of interest}

The authors declare no conflict of interest.

\section{Funding}

None.

\section{References}

1. Williams RG. Late causes of death after congenital heart defects: a population-based study from Finland. J Am Coll Cardiol. 2016;68:499-501.

2. Ryan TD, Chin C. Pediatric cardiac transplantation. Semin Pediatr Surg. 2017;26:206-12.

3. Tabarsi N, Guan M, Simmonds J, Toma M, Kiess M, Tsang V, et al. Meta-analysis of the effectiveness of heart transplantation in patients with a failing Fontan. Am J Cardiol. 2017;119:1269-74.

4. Márquez-González H, Miranda-Novales MG, Solórzano-Santos F, Klunder-Klunder M, Garduño-Espinoza J, Méndez-Galván JF. COVID-19 pandemic: challenges ahead. Bol Med Hosp Infant Mex. 2020;77:242-51.

5. Conacyt.mx. Información COVID-19. Mexico City: Conacyt; 2020. Available from: https://datos.covid-19.conacyt.mx.

6. Calderón-Colmenero J. Regionalization of congenital heart disease care: a pending goal. Arch Cardiol Mex. 2019;89:138-46.

7. Calderón-Colmenero J, Cervantes-Salazar JL, Curi-Curi PJ, Ramírez-Marroquín S. Problemática de las cardiopatías congénitas en México: propuesta de regionalización. Arch Cardiol Mex. 2010;80:133-40.

8. Comitedebioética.es. Declaración del Comité de Bioética de España sobre el derecho y el deber de facilitar el acompañamiento y la asistencia espiritual a los pacientes con covid-19 al final de sus vidas y en situación de especial vulnerabilidad. Madrid: Comité de Bioética de España; 2021. Available from: http://assets.comitede bioética.es/files/ documentación/CBE-Declaracion-sobre-acompañamiento-COVID19.

9. Sanches MA, Rocha CT, Surugi SS, de Siqueira JE. Perspectivas bioéticas sobre la toma de decisiones en tiempos de pandemia. Rev Bioet. 2020;28:410-7.

10. Janine RR, Várnagy $T$, Ciriza $A$, Chaui $M$, Grüner E, et al. Bentham: el Utilitarismo y la Filosofía Política Moderna. In: Boro A (compiler). La filosofía política moderna. De Hobbes a Marx. Buenos Aires: CLACSO; 2000. pp. 269-88.

11. Sánchez-Migallon GS [Tesis]. El personalismo ético de Dietrich Von Hildebrand. Un estudio a través del "Bien objetivo para la persona". Pamplona: Universidad de Navarra; 2002.

12. coronavirus.onu.org.mx. Geneva: World Health Organization; 2021. Available from: https://coronavirus.onu.org.mx.

13. Radke RM, Frenzel T, Baumgartner H, Diller GP. Adult congenital heart disease and the COVID-19 pandemic. Heart. 2020;106:1302-9.

14. Beauchamp T, Childress J. Principios de ética biomédica. Barcelona: Masson; 1999. 